\begin{tabular}{|c|c|c|}
\hline & $\begin{array}{l}\text { International Journal of Environment, Agriculture and Biotechnology } \\
\text { Vol-6, Issue-6; Nov-Dec, } 2021\end{array}$ & $\theta=$ \\
\hline IJEAB & $\begin{array}{c}\text { Journal Home Page Available: } \underline{\text { https://ijeab.com/ }} \\
\text { Journal DOI: } 10.22161 / \text { ijeab }\end{array}$ & \\
\hline
\end{tabular}

\title{
Characterization and evaluation of the antibacterial
} potential of bacterial microbiota of cultivated soils of Cassava (Manihot esculenta) and Black pepper (Piper nigrum) in the city of Igarapé Açu - Pará, Brazil.

\author{
Nilson Veloso Bezerra, Jonatan Carlos Cardoso da Silva, Juliana Hiromi Emin Uesugi, \\ Caroline Ferreira Fernandes, Maria Clara Coelho Prazeres, Daniel dos Santos Caldas, \\ Jose Alyson Rocha Pismel, Hadassa Hanna Soares Martins, José de Sena Gomes Júnior
}

Microbiology Aplicated Laboratory, University from Pará State, Brazil

Email: gebac.labmicro@gmail.com

Received: 28 Sep 2021; Received in revised form: 04 Nov 2021; Accepted: 14 Nov 2021; Available online: 22 Nov 2021 (C2021 The Author(s). Published by Infogain Publication. This is an open access article under the CC BY license (https://creativecommons.org/licenses/by/4.0/).

\begin{abstract}
Actinobacteria form a heterogeneous group of Gram-positive bacteria that have a great morphological and metabolic variety, are microorganisms with great biotechnological potential for the production of several substances of industrial and pharmaceutical interest, being considered the main source of antibiotics. Due to the increase in the occurrence of bacteria that are multiresistant to antibiotics used in clinical and hospital routine, the need to discover new substances with antibiotic capacity becomes evident. Thus, studies that assess the diversity and variety, composition and properties of metabolites produced by bacterial species present in cultivated soils are important and necessary. This work aimed to investigate the occurrence of actinobacteria in rhizosphere soils of areas cultivated with cassava (Manihot esculenta) and black pepper (Piper nigrum) in the city of Igarapé Açu - Pará, Brazil, to assess their potential as producers of antimicrobial substances. This is an analytical descriptive, experimental study that performs a microbiological analysis of soil samples. With great morphological diversity, 21 different bacteria were isolated, all with characteristics of actinobacteria. As a result, strains of actinobacteria with variable colonial characteristics were isolated, microscopically characterized as isolated and chained Gram-positive bacilli. Among the isolates, 8 strains were able to inhibit the growth of Escherichia coli and Klebsiella pneumoniae compared to in vitro. It emphasizes the need for more research aimed at the microbiology of Amazonian soils, due to the diversity of bacteria of biotechnological importance that can significantly contribute to the production of new antibiotics, thus generating a positive expectation in the fight against infections.
\end{abstract}

Keywords - Actinobacteria, rhizosphere, Manihot esculenta, Piper nigrum, Amazon.

\section{INTRODUCTION}

Soil is considered an important source of chemically diverse and biologically active substances; these compounds have been of great importance for industry and especially for pharmaceuticals. The microbiota in this ecosystem is extremely rich and the bioprospecting of several microorganisms and the analysis of their metabolic activities allow the discovery of potential antibacterial agents and other substances of industrial interest ${ }^{1,2}$.

Actinobacteria produce secondary metabolites with different chemical structures and biological activities, and many of these substances have been used to produce drugs for the treatment of various harm to human health and other organisms ${ }^{3}$. 
The Actinobacteria class is divided into 4 subclasses, 5 orders, 14 suborders, 50 families, 197 genera and 1936 species $^{4}$, they are mostly Gram-positive, aerobic bacteria ${ }^{5}$, with high content of $\mathrm{G}+\mathrm{C}$ in their DNA ${ }^{6}$, similar to some fungi, these bacteria reproduce mainly by sporulation, in which each spore produced can give rise to a new organism ${ }^{7}$.

Soils used for agriculture have different characteristics from uncultivated areas, due to anthropic action, type of fertilization and soil management can change the composition of the bacterial community in quantity and quality of microorganisms found in their rhizospheres ${ }^{8,9}$.

The microorganisms present in the rhizosphere community of cultivated soils are of great importance for plants, as they influence their development and protect the roots against pathogens ${ }^{10}$.

The search for new species of actinobacteria in these places is an essential component for the discovery of new substances and, based on the properties presented by actinobacteria, the study of microorganisms present in rhizosphere environments is of great importance, which can provide the discovery of new compounds and products of biological origin, with biotechnological potential for the production of metabolites with antibacterial action or other pharmaceutical and industrial applications.

The Amazon population still practices on a large-scale subsistence culture in small areas of land. Cassava (Manihot esculenta Crantz) and black pepper (Piper nigrum), are plants adapted to the tropical region, resistant to heat, demanding moisture and rainfall ${ }^{11}$, both highly cultivated in regions of the state of Pará. The objective of this work is to characterize and evaluate the antibacterial potential of bacterial microbiota of cultivated soils of cassava (Manihot esculenta) and black pepper (Piper nigrum) in the city of Igarapé-ace - Pará.

\section{MATERIAL AND METHODS}

- Sample collection:

To carry out this work, 24 soil samples were used, collected in groups of 4 samples at each point. The collection will take place through the use of sterile spatulas and the samples will be packed in disposable and sterile bags. Each sample will have $100 \mathrm{~g}$ of soil from each collection point, which will be georeferenced to meet the need for subsequent collections if necessary.

\section{2 - Isolation of microorganisms}

For bacterial isolation, samples from the rhizosphere, before seeding for bacterial isolation, underwent a pretreatment consisting of a $10 \mathrm{~g}$ dilution of the sample in
$90 \mathrm{~mL}$ of sterile saline solution, followed by vertexing for 10 to 20 minutes. After shaking, each sample was heated in a $50^{\circ} \mathrm{C}$ water bath for 10 minutes, aiming to eliminate contaminating bacteria that spread quickly and are not the target of isolation. The resulting supernatant was seeded using the surface streak method, using $0.05 \mathrm{~mL}$ sterile and disposable loops, in 3 Petri dishes containing the culture media: modified Czapeck Agar, modified Hickey-Tresner Agar and the culture medium Vitamin Arginine. In all culture media, Amphotericin B $(100 \mu \mathrm{g} / \mathrm{mL})$ was added to inhibit fungal growth. Petri dishes were incubated in a humid chamber bacteriological incubator for 24 hours up to 30 days at a temperature of $37^{\circ} \mathrm{C}$ to $45^{\circ} \mathrm{C}$ with daily visual observation of bacterial colony growth. The plates with bacterial growth were transferred to other plates and after purification they were kept in test tubes with slanted enrichment culture medium for their maintenance.

\section{3 - Bacteria characterization}

The isolated strains were characterized morphologically and physiologically through morphological characteristics of the colonies, microscopic characteristics of microorganisms and their metabolism through tests 8 biochemical tests. The macroscopic characterization was carried out by visual observation of color, shape and moisture characteristics, the evaluation of the microscopic aspect was carried out after making smears made of each characterized colony that were stained by the Gram stain method. The methodologies used in the biochemical tests were adapted from the manual of the National Health Surveillance Agency ${ }^{12}$, the tests used were: Oxidase test, catalase test, Simmons Citrate test, Hemolysis test, TSI test (Triple Sugar Iron)

\section{4 - Antimicrobial Sensitivity Test (TSA)}

The TSA was performed using the diffusion test on plates containing Muller Hinton Agar, and the potential for inhibiting the growth of Klebsiella pneumoniae, Staphylococcus aureus and Escherichia coli strains was evaluated, bacterial suspensions were prepared with an approximate concentration of $0.5 \mathrm{cfu}$. $/ \mathrm{mL}$ and the suspensions were used to seed plates containing Muller Hinton agar medium, using sterile disposable swabs, after 30 minutes at room temperature, the isolated and characterized strains from the soil were inoculated and pricked at specific points in the previously seeded plates, the formation of bacterial growth inhibition halos around the bite was considered a potential inhibiting power.

\section{RESULTS}

Despite the simplified methodology, this work clearly demonstrates the possibility of the existence of bacteria 
with biotechnological potential in the Amazon region. The antibacterial action of the isolates against Gram-positive bacteria such as $S$. aureus was not found in this research, but on Gram-negative bacteria such as Escherichia coli and Klebsiella pneumoniae there was inhibition of bacterial growth in vitro, this action was also described by Silva ${ }^{7}$, in which only Gram-negative bacteria were affected.

The Amazonian soil microbiota is characterized by abundance and diversity, our findings were characterized by the isolation of bacteria with various macro and microscopic morphologies, similar to the results ${ }^{13,10}$. The organisms found in this research showed a wide morphological variety, but the presence of isolated Grampositive bacilli or in chains predominated, similar findings are described in the literature, reinforcing the assertion of the vast amount of these microorganisms in the soil ${ }^{3}$.

Ecological studies of actinomycetes populations are extremely important, as these microorganisms form spores and conidia, allowing their survival in adverse conditions 14. In addition, actinomycetes stand out for the possibility of synthesizing vitamins, substances that inhibit enzymatic activity ${ }^{15}$, antibiotics and other biologically active compounds ${ }^{16}$.

There was bacterial growth at all collection points, with no growth restriction in relation to the soil depth in the places. Isolated colonies were macroscopically characterized based on their color and appearance presented in the media used. (Table 1).

The microscopic analysis of bacterial colonies, performed using the Gram stain technique, showed a great diversity of bacterial morphologies (Figure 1), described isolated and paired Gram-positive bacilli (BGPi), Gram positive coccobacillus (CBGP), Gram bacilli chain positives (BGPc) and grouped and isolated Gram-positive cocci (CGP), distributed according to table 2.

The biochemical characterization of the isolated colonies was performed using biochemical tests according to table 3.

In rhizosphere soils of black pepper, 13 plates with bacterial growth were analyzed, which presented colony characteristics similar to those of cassava. (Table 4).

Considering the morphology of the bacteria found through the Gram staining technique, they were identified in isolated and paired Gram-positive bacilli (BGPi), Gram positive coccobacillus (CBGP), Gram positive bacilli in chain (BGPc) and Gram-positive cocci grouped and isolated (CGP), distributed according to table 5.

The biochemical characteristics of colonies isolated from rhizosphere soil samples of black pepper did not show any difference from the characteristics isolated from rhizosphere soils of cassava. For the evaluation of the sensitivity test and antimicrobial activity of the strains, all 33 bacterial strains isolated were submitted to the methodology (Figure 2), of which only 8 strains showed inhibitory activity on the tested bacteria (Table 6).

\section{FIGURES AND TABLES}

Table 1: Macroscopic characteristics of bacterial colonies isolated in cassava rhizosphere:

\begin{tabular}{l|l|l}
\hline Colonial type & N & \% \\
\hline Mucoid white & 8 & 38 \\
Dry white & 6 & 28,5 \\
White cotton & 4 & 19,2 \\
Mucoid yellows & 3 & 3 \\
\hline Total & $\mathbf{2 1}$ & $\mathbf{1 0 0 , 0}$ \\
\hline
\end{tabular}

Source: Authors

Table 2: Microscopic characteristics of bacterial colonies isolated in cassava rhizosphere.

\begin{tabular}{l|l}
\hline Colonial type & Microscopy \\
\hline Mucoid white & CGP e BGPc \\
Dry white & BGPi e BGPc \\
White cotton & BGPi e BGPc \\
Mucoid yellows & CBGP \\
\hline
\end{tabular}

Source: Authors

CGP: Gram-positive cocci; BGPc: Gram-positive bacilli in chain; BGPi: Isolated Gram-positive bacilli; CBGP: Grampositive coccobacilli.

Table 3 - Biochemical characterization of colonies isolated from cassava rhizosphere.

\begin{tabular}{l|l|l|l|l|l|l|l|l}
\hline Colonial type & TSI & L & S & M & C & H & O & C \\
\hline Mucoid white & Ac/Alc & v & v & - & - & + & + & + \\
Dry white & Ac/Alc & + & + & - & - & + & + & + \\
White cotton & Ac/Alc & + & $\mathrm{v}$ & - & - & + & + & + \\
Mucoid yellows & Ac/Alc & + & + & - & - & + & - & - \\
\hline
\end{tabular}

Source: Authors

Captions: TSI: Triple sugar with iron, L: Lactose, S: Sucrose, M: Motility, C: Simmons citrate, H: Hemolysis test, O: Oxidase, C: Catalase.

+ Positive proof, - Negative proof, v: variable result. 
Table 4: Macroscopic characteristics of bacterial colonies isolated in black pepper rhizosphere:

\begin{tabular}{l|l|l}
\hline Colonial type & N & \% \\
\hline Mucoid white & 3 & 23,05 \\
Dry white & 3 & 23,05 \\
White cotton & 2 & 15,4 \\
Mucoid yellows & 5 & 38,5 \\
\hline Total & $\mathbf{1 3}$ & $\mathbf{1 0 0 , 0}$ \\
\hline
\end{tabular}

Source: Authors

Table 5: Microscopic characteristics of bacterial colonies isolated in black pepper rhizosphere:

\begin{tabular}{l|l}
\hline Colonial type & Microscopy \\
\hline Mucoid white & CGP e BGPc \\
Dry white & BGPi e BGPc \\
White cotton & BGPi e BGPc \\
Mucoid yellows & CBGP \\
\hline
\end{tabular}

Source: Authors

CGP: Gram-positive cocci; BGPc: Gram-positive bacilli in chain; BGPi: Isolated Gram-positive bacilli; CBGP: Grampositive coccobacilli

Table 6-Biochemical characterization of colonies isolated from cassava rhizosphere.

\begin{tabular}{l|l|l|l|l|l|l|l|l}
\hline Colonial type & TSI & L & S & M & C & H & O & C \\
\hline Mucoid white & Ac/Alc & v & v & - & - & + & + & + \\
Dry white & Ac/Alc & + & + & - & - & + & + & + \\
White cotton & Ac/Alc & + & $\mathrm{V}$ & - & - & + & + & + \\
Mucoid yellows & Ac/Alc & + & + & - & - & + & - & - \\
\hline
\end{tabular}

Source: Authors

Captions: TSI: Triple sugar with iron, L: Lactose, S: Sucrose, M: Motility, C: Simmons citrate, H: Hemolysis test, O: Oxidase, C: Catalase.

+ Positive proof, - Negative proof, v: variable result.

Table 7 - Sensitivity test of colonies isolated in cassava rhizosphere.

\begin{tabular}{l|l|l|l}
\hline Colonial type & E.coli & K.pneumoniae & S.aureus \\
\hline Cottony white & + & + & - \\
\hline Dry white & - & - & - \\
\hline
\end{tabular}

\begin{tabular}{l|l|l|l}
\hline Mucoid white & + & - & - \\
\hline Mucoid yellow & + & + & - \\
\hline Source: Authors
\end{tabular}

Source: Authors

(+) Positive inhibition test

(-) Negative inhibition test

Figure 1 - A and B - Isolated and paired Gram-positive bacilli (BGPi), C, D and E Gram positive bacilli in chains (BGPc) (filamentous).

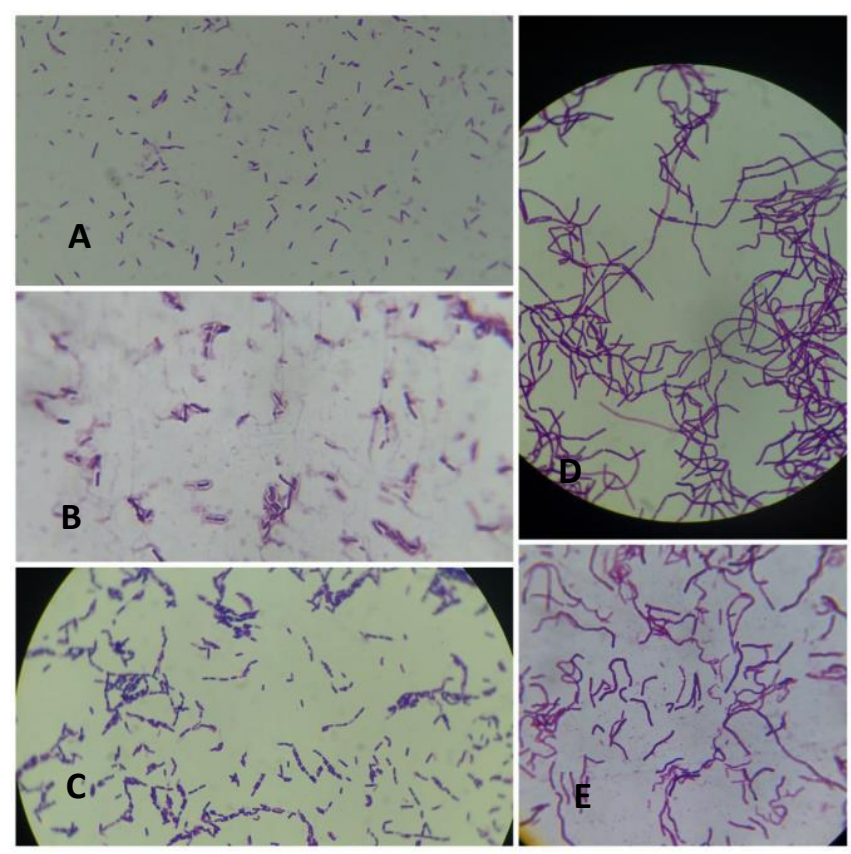

Source: Authors

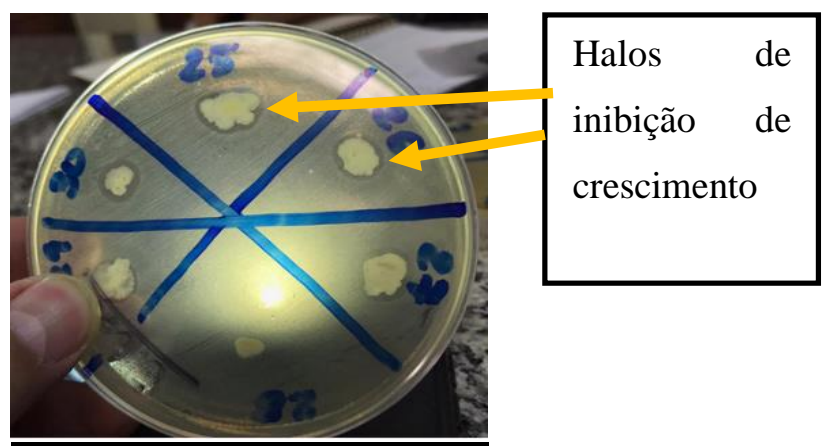

Source: Authors

Fig.2: Sensitivity test demonstrating inhibition of Gramnegative bacteria growth by actinobacteria from isolated soils.

\section{CONCLUSION}

The Amazonian soil is still little explored in its biotechnological potential, the findings in this research demonstrate the possibility of discovering new bacterial strains with high potential for the production of new antibacterial drugs. Bacteria isolated from these soils 
proved to be organisms with relevant pharmaceutical potential. These organisms act as growth inhibitors of other microorganisms and are key agents in the biocontrol of diseases of human pathogens, and can significantly contribute to the production of antibiotics, thus generating a positive expectation in the fight against infections. The expected scientific benefits of greater knowledge about microbial diversity include, among others, better understanding of the roles played by microbial communities in terrestrial environments and knowledge of their interactions with other components of biodiversity.

Despite being relevant in several aspects, soil bacteria are still poorly studied and disseminated. It is proposed to carry out more in-depth research on the applications of actinobacteria in these processes, using more accurate tests and techniques to achieve these findings in order to highlight the economic importance of soil biota, and support the review and synthesis of the direct value and indirect soil biological species.

\section{ACKNOWLEDGEMENTS}

University of the State of Pará.

\section{REFERENCES}

[1] CORRÊA, G.G.; SILVA, L.L.; LINS, M.R.C.R.; SILVA, W.O.; LOPES, W.; ARAUJO, E.A.; VASCONCELOS, N.B.; SOURCES VIEIRA, J.M.; SILVA, D.T.F.; LIMA, G.M.S.; ARAUJO, J. M. Isolation and antimicrobial activity of actinobacteria from the Caatinga rhizosphere. Federal University of Pernambuco, Recife PE, 2014.

[2] ESCHER, S K S. Bioprospection of actinobacteria isolated from the rhizosphere of Aniba parviflora Syn fragans (Macacaporanga) from Amazonia and evaluation of antimicrobial activity. Thesis (Doctorate). Federal University of Pernambuco. Graduate Program in Pharmaceutical Sciences. Recife, 2016.

[3] FRANCO, C.M.M. \& COUTINHO, L.E.L. Coutinho, Detection of Novel Secondary Metabolites, Critical Reviews in Biotechnology, 11:3, 193-276, 1991.

[4] BORA, N.M.; WARD, A.C. The actinobacteria. In: GOLDMAN, E.; GREEN, L.H. (Ed). Practical handbook of microbiology. 2. ed. Boca Raton: CRC Press, 2009, p. $373-$ 443.

[5] SANTOS, J.D. Analysis of the dominant microbiota of three sampling points in the Amazon savanna soil with potential for the production of bioactives. Federal University of Amapá. Dean of research and postgraduate research department and postgraduate master's degree in health sciences. 2012.

[6] VENTURA, M., CANCHAIA, C., TAUCH, A, CHANDRA, G., FITZGERAL, GF, CHATER, KF, van SINDERAM, D., Genomics of Actinobacteria: Tracing the Evolutionary History of an Ancient Phylum, Microbiology and Molecular Biology Reviews 71(3):495-548 - October 2007.

[7] SILVA, G. R. Bioprospection of actinobacteria isolated from the rhizosphere of Caesalpinia pyramidalis Tul. of the Caatinga biome. Federal University of Pernambuco, 2013.

[8] BRITO, P.H.; \& NASCIMENTO, R. P. Evaluation of the enzymatic potential of actinobacteria isolated from coastal environments. XII Brazilian Seminar on Enzymatic Technology ENZITEC 2016. Federal University of Rio de Janeiro. Chemistry school. 2016.

[9] CANOVA, S.P. Diversity and Bioprospecting of Actinobacteria Isolated from Mangroves. Dissertation (Masters in Biotechnology). Institute of Biomedical Sciences, University of São Paulo, São Paulo, 66 f. 2009.

[10] SÁ, F.O., Biological control of sisal red rot (Agave sisalana Perrine) with Trichoderma ssp. And Actinobacteria. 2014. 133f. Thesis (Doctorate in Agricultural Sciences) - Federal University of Reconcavo da Bahia, Cruz das Almas, BA, 2014.

[11] RAMOS, B.C.N., Review of the literature of the microbiological study of pepper spice (Piper nigrum). Dissertation (Masters in Agricultural Sciences) - Federal University of Maranhão, São Luiz, MA, 2018.

[12] BRAZIL. National Health Surveillance Agency Clinical Microbiology for the Control of Infection Related to Health Care. Module 6: Detection and identification of medically important bacteria / National Health Surveillance Agency. Brasília: Anvisa, 2013. 150p..: il.9 volumes.

[13] SOUSA, V.Y.K. Bioprospection of antimicrobial agents among environmental bacteria and medicinal plants from the Amazon. Faculty of Agronomy and Veterinary Medicine, University of Brasília, 69p. Masters dissertation. Brasilia, 2012.

[14] VOBIS, G. Morphology of Actinomycetes. In: MIYADOH, S. Atlas of Actinomycetes. Japan: Asakura, p. 180-191, 1997.

[15] TAGUCHI, S. et al. Streptomyces subtilisin inhibitor-like proteins are widely distributed in Streptomycetes. Applied and Environmental Microbiology, Washington, v. 59, no. 1, p. 4338-4341, 1993.

[16] PEREIRA, J.C.; NEVES, M.C.P.; DROZDOWICZ, A. Quantifications of bacterial populations in general, antibiotic resistant bacteria and Actinomycetes in soils. Seropédica: EMBRAPA-CNPAB, 1996. 21 p. 